\title{
Contribution of Rural Non-Farm Enterprises to Buen Vivir in Protected Areas in the Amazon
}

By Pedro Henrique Mariosa, Henrique Dos Santos Pereira, Veridiana Vizoni Scudeller, Maria Olívia De Albuquerque Ribeiro Simão \& Duarcides Ferreira Mariosa

Federal University of Amazonas

Abstract- Rural non-farm activities are adaptation strategies that local communities develop as socioeconomic alternatives, for facing imposed restrictions in protected areas. To highlight these strategies, this study aimed to relate the socioeconomic variables of social agents (SAs) with their perceptions about the impact of rural non-farm enterprises (RNFEns) on the Buen Vivir of their community as residents of the Sustainable Development Reserve of Tupé, Manaus, Amazonas. In this exploratory research, through semi-structured interviews and participatory observations, the perceptions of the SAs about the dimensions of Buen Vivir (Psychological Well-Being, Time Use, Community Vitality, Culture, Environment, and others) were evaluated and how these perceptions relate to the socioeconomic variables of the RNFEns. In the perception of the SAs, the RNFEns positively impact Buen Vivir in the dimensions with the strongest collective tendency and negatively in the dimensions with the strongest private tendency, with pluriactivity being the explanatory variable.

Keywords: rural non-farm activities; sustainable development reserve; lower rio negro; pluriactivity.

GJHSS-H Classification: FOR Code: 149999

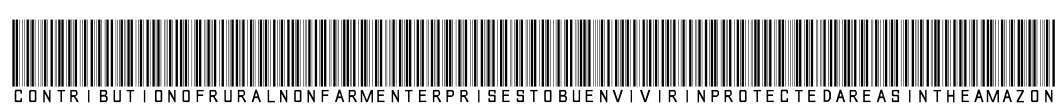

Strictly as per the compliance and regulations of:

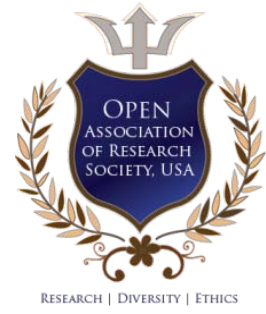

(c) 2021. Pedro Henrique Mariosa, Henrique Dos Santos Pereira, Veridiana Vizoni Scudeller, Maria Olívia De Albuquerque Ribeiro Simão \& Duarcides Ferreira Mariosa. This is a research/review paper, distributed under the terms of the Creative Commons Attribution-Noncommercial 3.0 Unported License http://creativecommons.org/licenses/by-nc/3.0/), permitting all non-commercial use, distribution, and reproduction in any medium, provided the original work is properly cited. 


\title{
Contribution of Rural Non-Farm Enterprises to Buen Vivir in Protected Areas in the Amazon
}

\author{
Pedro Henrique Mariosa ${ }^{\alpha}$, Henrique Dos Santos Pereira ${ }^{\sigma}$, Veridiana Vizoni Scudeller ${ }^{\rho}$, \\ Maria Olívia De Albuquerque Ribeiro Simão ${ }^{\omega} \&$ Duarcides Ferreira Mariosa ${ }^{*}$
}

\begin{abstract}
Rural non-farm activities are adaptation strategies that local communities develop as socioeconomic alternatives, for facing imposed restrictions in protected areas. To highlight these strategies, this study aimed to relate the socioeconomic variables of social agents (SAs) with their perceptions about the impact of rural non-farm enterprises (RNFEns) on the Buen Vivir of their community as residents of the Sustainable Development Reserve of Tupé, Manaus, Amazonas. In this exploratory research, through semi-structured interviews and participatory observations, the perceptions of the SAs about the dimensions of Buen Vivir (Psychological Well-Being, Time Use, Community Vitality, Culture, Environment, and others) were evaluated and how these perceptions relate to the socioeconomic variables of the RNFEns. In the perception of the SAs, the RNFEns positively impact Buen Vivir in the dimensions with the strongest collective tendency and negatively in the dimensions with the strongest private tendency, with pluriactivity being the explanatory variable.
\end{abstract}

Keywords: rural non-farm activities; sustainable development reserve; lower rio negro; pluriactivity.

\section{INTRODUCTION}

T he possibility of implementing the Sustainable Development Goals (SDGs) necessarily passes through actions developed exclusively or mainly in rural areas, since they represent $78 \%$ of the 169 corresponding SDG targets (BERDEGUE, 2019). In this sense, it is necessary to monitor the dynamics of rural employment in the country, since this has been changing in recent decades with the increase in the actions of family economic units that start to undertake, in greater intensity, non-agricultural activities, replacing strictly agricultural activities (MATTEI, 2015; SCHNEIDER, 2009).

Enterprises managed by familial economic units in rural areas have a greater capacity to positively influence the social cohesion of a community, than conventional companies in urban centers (VLIET et al., 2015).

Author a: Dr. Student in Environmental Science and Sustainability of the Amazon. Professor in Federal University of Amazonas.

e-mail: pedromariosa@ufam.edu.br

Author G: Ph.D. in Ecology and Full Professor in Federal University of Amazonas.e-mail: hpereira@ufam.edu.br

Author p: Dr. in Plant Biology and Professor in Federal University of Amazonas.e-mail: vscudeller@ufam.edu.br

Author w: Dr in Freshwater Biology and Professor in Federal University of Amazonas.e-mail: mariaoliviar@uol.com.br

Author: Dr. in Sociology and Professor in Pontifical Catholic University of Campinas.e-mail: duarcides@gmail.com
Studies on different impacts of rural non-farm activities on economic and social issues are growing in Brazil and worldwide (FAIGUENBAUM; BERDEGUE; REARDON, 2002; HAGGBLADE; REARDON; HYMAN, 2007; HAGGBLADE; HAZELL; REARDON, 2010; MATTEI, 2008; MATTEI, 2015; NUNES; MARIANO, 2015; REARDON; STAMOULI; PINGALI, 2007). In this sense, it is desirable, in the complementation of these economic and social studies, other studies focusing on the impact of these activities in the environmental, ecological, political, and cultural dimensions.

According to Brazilian legislation, rural areas occupied by traditional communities may be declared under special environmental protection, which is the case of Sustainable Development Reserves (SDR) as Conservation Units (CUs). In these CUs, rural, farm, and non-farm economic activities area allowed and promoted as they are believed to guarantee the conservation of the environment and at the same time ensure the social reproduction of local communities (BRASIL, 2000).

Nevertheless, the lack of clarity in the regulation of agricultural and non-agricultural activities in protected areas causes uncertainty regarding the economic and environmental risks to which social agents (SAs) are subject. In the specific case of the locus of this study, the Tupé RDS, there are gaps in the Management Plan (SEMMAS, 2016; 2017), which does not accurately determine the economic activities allowed in the Intensive Use areas, which are specific areas for the undertaking activities that guarantee the social reproduction of the RDS SAs. This context influences the change in the dynamics of rural employment in the locality and, therefore, the SAs starts to develop income generation strategies with a greater focus on nonagricultural activities.

The change in the dynamics of rural employment and the association of multiple rural activities as an alternative, whether agricultural or nonagricultural, in this study, is seen as pluriactivity, a characteristic common to all the SAs in this research. De-Silva; Kodithuwakku (2010) consider pluriactivity as a survival strategy and Kinsella et al. (2000) points out that this pluriactivity must be understood broadly and not as just the combination of agriculture with other nonagricultural activities. In this sense, Loughrey et al. (2013) points out that the greater the number of 
activities, added to the entrepreneurial quality of their ASs, the lesser the dependence of family economic units on obtaining income outside their properties, however the greater the barriers for the succession of the rural property. As the RDS is treated as a territory for collective use, the concept of pluriactivity by Fuller (1990) and Capellesso and Cazella (2011) should be preferred, since these authors consider pluriactivity within the territoriality where the activities are developed.

Much earlier, Evans and Ilbery (1993) already signalled that the understanding of pluriactivity as a category of analysis must combine these two complex phenomena, part-time agriculture and agricultural diversification, to form a broader term of reference. Fuller (1990) already exalted it within a theoretical discussion that included, in addition to these two aspects, unpaid activities (financially) within the process, opening the concept of pluriactivity to formal and informal work relationships.

Given the complexity of endogenous and exogenous factors that affect the SAs that undertake economic activities in SDR, there is a need to expand the dimensions of economic analysis of the enterprises. If, on the one hand, there is a high reliability in the studies carried out on the rural non-farm economy, on the other hand, the targeting of these consists predominantly in the assessment of the impact of nonagricultural activities in the economic and social spheres of local development.

Within this territorial perspective of activities, there is a need to incorporate issues beyond the economic sphere of activities, always seeking to overcome modernist/colonial pre-notions about the dynamics of the work of traditional populations in rural areas and, finally, syncretize the forms of organization, worldviews, and the guarantee of social reproduction of these populations, with the need to conserve areas with special environmental protection.

This search for perspectives that invert the logic of development based on a colonial/modernist vision and that starts to give prominence to traditional ways of life in interrelation with the environment, have emerged in several places in South America, with greater representation in countries like Bolivia and Ecuador, paths that have come to break with the socio-economic anthropocentric vision, and suggest developing differentiated political measures, laws and norms as a matrix economic model. One of these perspectives, which proposes the inversion of the colonial developmental model, is the so-called Well Living or Good Living (translated of Buen Vivir), a polysemic concept.

This polysemy translates into multiple ways of interpreting its concept by academia and society, with emphasis on: a) perspective for a new paradigm of production and consumption (MORAIS; BORGES, 2010; ATAWALLPA, 2014; SPARN, 2019; MORA, 2020); b) process of changing the ethical/political perspective (ACOSTA, 2012; QUIJANO, 2012; ENDERE and ZULAICA, 2015; LACERDA and FEITOSA, 2015; ALCANTARA and SAMPAIO, 2017a); and, c) alternative approach to modernist/colonial development (QUIJANO, 2012; KOTHARI; DEMARIA and ACOSTA, 2015; MERINO, 2016; ALCANTARA and SAMPAIO, 2017a, 2017b; COSTA and KÜHN, 2019). Whether as a paradigm, process or approach, there is alignment in relation to the core of Buen Vivir about its ability to bring to the centre "(...) social movements, from themes such as ecology to feminism, have regained their centrality in people's lives and in nature, in the defence of basic rights, such as education, health and social equality..." (ALCANTARA and SAMPAIO, 2017a, p. 232).

For these authors, the concept of Buen Vivir has an Andean origin, spanning from southern Venezuela to northern Argentina and is derived from two indigenous peoples, the Quechua (Ecuador) and the Aymara (Bolivia). There are other authors who, in addition to the origin of Buen VIvir in the Quechua and Aymara peoples, also point to Guarani (IHU, 2010) and Baniwa (CRUZ, 2015).

Alcantara and Sampaio (2017a) emphasize that the concept does not remain in its theoretical sphere, emphasizing the Buen Vivir as a debate around alternative development proposals that consider the relationship between environment and society. Buen Vivir is an important tool for overcoming mechanistic economic growth and Brazil has the potential for its incorporation based on its cultural, ecological, and human diversity (ACOSTA, 2012).

Endere and Zulaica (2015) use the guidelines of the 2013-2017 National Good Living Plan of Ecuador as guiding a qualitative indicator for assessing the sociocultural sustainability of an archaeological site located in an area with special environmental protection. Other authors also use Buen Vivir as a guide for the development of qualitative indicators. Morais and Borges (2010) have instrumentalized a methodological conception about Buen Vivir that, in addition to excelling for new production and consumption paradigms, takes advantage of the conceptual proximity of Gross Domestic Happiness (FIB), which consists of a methodology alternative to the Gross Domestic Product (GDP) conventional approach.

Morais and Borges (2010), then, elaborate a methodological script on Buen Vivir, based on qualitative analyses that seek to understand the capacity of a project/enterprise to impact the quality of life based on the perception of social agents. The objective of the Buen Vivir script is to understand what the issues are projects collectively limit or boost the Well Living of SAs and the Community to which they belong.

Based on the studies by Morais and Borges (2010) and Endere and Zulaica (2015), this study intends to broaden the perspective of Buen Vivir by 
conceiving it as a theoretical and methodological basis for the rupture of purely economic models, with scope for enterprise evaluation, projects, and other civil society initiatives.

In conducting this study, we aim to find the answers to a central question: how do SAs perceive the impact of their enterprise on Buen Vivir of the Community? Our objective is also to assess how the socioeconomic characteristics of the social agents affect their perceptions about the impact of the enterprises in the collective dimensions of the Community.

\section{METHOD}

This study was carried out at the headquarters of Livramento Community, located in the Tupé Sustainable Development Reserve (Tupé SDR), 25 km away from Manaus downtown area (SCUDELLER et al., 2005), with 20 SAs responsible for 21 enterprises that perform rural non-farm activities, from March to September of 2017. Each Rural Non-Farm Enterprise was identified by a number (random numerical sequence), and were conceived as the space used by the SAs, in which the family economic unit undertakes its activities. The social agent responsible for the economic activity was identified as "SAs $\mathrm{n}^{\circ}$ (random number sequence)". This social agent was identified as the reference person for providing the perceptions of Buen Vivir. Regarding the concept of traditional populations, traditional people, and communities, we follow the National Policy for Sustainable Development of Traditional Peoples and Communities - PNPCT, in its Article 3, item I, which states that Traditional Peoples and Communities are:

"Culturally differentiated groups that recognize themselves as such, that have their own forms of social organization, that occupy and use territories and natural resources as a condition for their cultural, social, religious, ancestral and economic reproduction, using knowledge, innovations and practices generated and transmitted by tradition" (BRASIL, 2007).

Most of the SAs responsible for one of the enterprises identify themselves as belonging to the traditional community or people, whether Ribeirinhos (river dwellers) or indigenous. We followed the selfidentification principle, which for Almeida (2008) is the declaration of belonging to a people or group, as an identity factor, with the objective of claiming rights. Specifically, for the Ribeirinhos people, Neves (2009, p.89) states that these "are thus immediately identified when the reference highlights this environmental condition of life" and also concludes that this category, in relation to identity, is expressed as "(...) a category that is more political than economic, which is why it raises the qualifying remission of an advocate way of life as sui generis". Regarding the indigenous people in the
Livramento Community, according to one of the SAs, there are altogether 13 different ethnicities residing in the locality. However, there is a leadership role of the Baré ethnic group in the undertaking non-agricultural rural activities in the community.

Considering the diversity of the SAs, we sought to adapt the Roadmap to Buen Vivir as an instrument for assessing perceptions about the dimensions and the relationship with the socioeconomic profile of the SAs. Therefore, an emic approach was adopted, by which "members of cultural groups have their own interpretation of their culture" (ROSA and OREY, 2012, p.867). During the development of the research, a frequent dialogue with the SAs was maintained, from April to September 2017. This form of research relationship (BOURDIEU, 2008) allowed us to use creativity and innovation in the methodological processes, also minimizing the pre-notions (BACHELARD, 1996) about traditional populations in protected areas and, establishing a relationship of trust between the researchers and the SA subjects.

The interview script made it possible to record the SAs' assessments of the influence of enterprises on the multiple dimensions of individuals and the community during semi-structured interviews. These records were combined with the direct observations made during the fieldwork. The analysis of the discourses of the SAs were made qualitatively through content analysis (BARDIN, 2009), grouping the main themes within the following macro (dimensions) and micro (definitions) categories and main questions about Buen Vivir, adapted from Morais and Borges (2010):

a) Dimension: Psychological Welfare;

Definition: Satisfaction and optimism of the social agent in relation to one's own life;

Main Questions: Does the enterprise contribute positively to the quality of life? And in a negative way? How does the enterprise help to increase your confidence in a better life?

b) Dimension: Use of Time;

Definition: Distribution of time between work, family, friends, and other activities;

Main Questions: How much has the enterprise contributed to having more time available and thus developing other activities that you did not do before?

c) Dimension: Community Vitality;

Definition: Relationships and interactions in communities, sense of belonging, affective relationships, mobilization, and self-cooperation;

Main Questions: Has the enterprise changed your relationship with the Community? Are the enterprise and its respective SA invited to organize or participate in any collective action? 
d) Dimension: Culture (or culture diversity);

Definition: Maintain, affirm, and foster local traditions and cultures, existence of cultural and artistic events and discrimination based on religion, race, or gender;

Main Questions: Did the enterprise contribute to strengthen the region's traditional culture? Did the enterprise make the SAs participate more in the cultural activities of the Community?

e) Dimension: Environment (or ecological resilience);

Definition: Quality of water, air, soil, biodiversity, and the perception of the quality of the environment in general;

Main Question: How do you perceive the interference of the enterprise in the conservation of the Community environment?

f) Dimension: Governance and Citizenship (or good governance);

Definition: Participation and transparency in government decisions, social movements, media, judiciary, electoral system and the influence on citizenship and the enforceability of rights;

Main Questions: Does the undertaking, or does it not, make the SA remain more informed about its rights and duties? Does the enterprise make SA charge more for its rights, and exercise his/her duties more?

g) Dimension: Life Standard;

Definition: Material living conditions, individual and family income, debt level, housing, consumption patterns and financial security;

Main Questions: Does the enterprise change the income of the SA, in a positive or negative way? And your standard of living? What are the points most affected by this change in income?

h) Dimension: Health;

Definition: Health policies, self-rated health, disability, exercise, sleep, and nutrition;

Main Question: Did the enterprise contribute to improving the health of the SA?

i) Dimension: Education;

Definition: Formal, informal education, skills, children's education, values in education and environmental education;

Main Questions: Does the enterprise contribute or not to expand the knowledge of the AS, to bring new information about the Community, region, or the Country? Does the entreprise facilitate access to an educational service?

Based on the dimensions of Buen Vivir, thematic guiding questions were elaborated, carried out only when it did not reveal spontaneously during a semi- structured interview, thus allowing to fill existing gaps and allowing the later categorization of perceptions in positive, neutral, and negative, using the same categorization in macro and micro categories. (BARDIN, 2009). To reveal correlations between the dimensions and the profile of the respondents, initially a cluster analysis is established, using the Ward method, which for Tomaz, Peternelli and Martins-Filho (2010, p. 02) "consists of analysing the formation of groups by maximizing homogeneity within groups. The sum of squares within the groups is used as a measure of homogeneity" and has been adored to identify possible groupings considering minimal variations in the perception of SAs. For this analysis, the data were grouped in a matrix that lists the SAs and the dimensions Buen Vivir, with a value of 1 for perceptions of positive impact, 0 of neutral impact and -1 of negative impact.

To determine which one has the greatest potential for influencing perceptions, this same matrix had been used as a database for principal component analysis (PCA) that allows individuals to be grouped according to the variance of their characteristics (HONGYU, SANDANIELO and OLIVEIRA -JUNIOR, 2016). The values of main component 1 were used to relate the socioeconomic factors (Table 02) with the perceptions of the SAs, using a simple linear regression model (KRAJEWSKI, RITZMAN and MALHOTRA, 2009), in all the socioeconomic factors and the values of the first main component. Both ACP and simple linear regression were processed using the PAST 3.2 program (HAMMER, HARPER and RYAN, 2001).

All research followed a strict authorization process by all agents and social agencies involved and to comply with the norms of the Resolution of the National Health Council (CNS) 466/2012, the Research Ethics Council (CEP) of the Federal University of Amazonas approved this research through opinion No. 66467317.6.0000.5020.

\section{ili. Result and Discussion}

Livramento RNFEns have different profiles (Fig.1). Those related to the retail trade and food and beverages predominate, which correspond to $52 \%$ of the RNFEns and represent $76 \%(46,000$ of $60,800 \mathrm{R} \$)$ of the monthly income declared by the total of the RNFEns. 


\begin{tabular}{lcccccc}
\hline SA ID & Main Activity & $\begin{array}{c}\text { No Total } \\
\text { Activities }\end{array}$ & Workers & Lifetime & $\begin{array}{c}\text { Revenue } \\
5\end{array}$ & $\begin{array}{c}\text { Profit } \\
\text { Sharing }\end{array}$ \\
\hline SA 01 & Retail Business & 2 & 2 & 1 month & - & Individual \\
SA 02 & Drinks and Foods & 2 & 1 & 8 months & $800 \mathrm{R} \$$ & Familiar \\
SA 03 & Retail Business & 2 & 2 & 21 years & $4500 \mathrm{R} \$$ & Familiar \\
SA 04 & $\begin{array}{c}\text { Commercial } \\
\text { Representation }\end{array}$ & 2 & 1 & 8 months & - & Familiar \\
SA 05 & Drinks and Foods & 4 & 3 & 2 years & $1200 \mathrm{R} \$$ & Familiar \\
SA 06 & Dressed & 2 & 1 & 22 years & - & Individual \\
SA 07 & Drinks and Foods & 2 & 7 & 12 years & $1500 \mathrm{R} \$$ & Collective \\
SA 09 & Sports Association & 3 & 12 & 3 years & $5000 \mathrm{R} \$$ & Collective \\
SA 10 & Handmaid Art & 4 & 1 & 2 years & $800 \mathrm{R} \$$ & Individual \\
SA 11 & Cultural Association & 4 & 12 & 8 years & - & Collective \\
SA 12 & Retail Business & 4 & 3 & 2 years & $28000 \mathrm{R} \$$ & Assalariado \\
SA 13 & Drinks and Foods & 2 & 4 & 1 year & $2000 \mathrm{R} \$$ & Familiar \\
SA 14 & Transports & 2 & 1 & 15 years & $2000 \mathrm{R} \$$ & Familiar \\
SA 15 & Drinks and Foods & 4 & 6 & 15 years & $4000 \mathrm{R} \$$ & Collective \\
SA 16 & Cultural Project & 4 & 1 & 1 year & $1000 \mathrm{R} \$$ & Individual \\
SA 17 & Handmaid Art & 3 & 4 & 29 years & - & Familiar \\
SA 18 & Retail Business & 3 & 2 & 15 years & $5000 \mathrm{R} \$$ & Familiar \\
SA 19 & Retail Business & 4 & 2 & 22 years & $3000 \mathrm{R} \$$ & Familiar \\
SA 20 & Cultural Project & 2 & 2 & 4 months & - & Collective \\
SA 21 & Handmaid Art & 3 & 1 & 11 years & $2000 \mathrm{R} \$$ & Collective \\
\hline & & & & & & \\
& & & & & &
\end{tabular}

Fig. 1: Synthesis of the socioeconomic diagnosis of the Rural Non-Farm Enterprises ( $N=21$ ) of the Livramento Community.

A characteristic of RNFEns that differs from the logic of conventional enterprises is the sharing of the benefits obtained. The majority (76\%) of the SA declared that the sharing of the benefits obtained in the RNFEn is carried out in a collective or family way. This situation is intensified for 4 out of 5 RNFEns linked to retail business and drinks and food.

Another unique feature of this study is to consider both Enterprises and Sociocultural Associations as undertakings, as they play a relevant social role for the Well Being of the Community and that by definition "...are undertakings that focus their main business on solving, or minimizing, a problem social or environmental impact of a community" (SEBRAE, 2013). In this case, Baumel and Bass (2004) conception on pluriactivity is adequate to the research universe, since pluriactivity is configured in a social practice resulting from the search for alternative ways to guarantee the reproduction of families (...) in other occupational activities, in addition to of agriculture" (2004, p.139).

Territoriality was the guiding parameter to determine the list of activities of an RNFEn and not just in a specific physical space. This view was considered based on Capellesso and Cazella (2011) that associates pluriactivity with the territoriality of the activities developed, which can be developed exclusively outside rural activity or concomitantly.

a) The Buen Vivir of the Collective to the Individual

When dealing with public policies in the Health dimension or addressing the quality of life in the
Psychological Welfare and Life Standard dimensions, this "quality of life" does not mean a scale between living poorly or living well, or of living better by providing from modern-western concepts, or international public health standards, but to the set of values that translate into the conceptions of the SAs on Buen Vivir, quality of life, environment and health.

The dimensions of Buen Vivir are related to both the sphere of private life and that of the community, in different degrees. The following dimensions were considered to have the greatest tendency to the private sector: Psychological Welfare, Use of Time, and Health; in a neutral trend the dimensions: Environment, Governance and Citizenship and Standard of Living; and in a greater tendency towards collectively, the dimensions: Culture, Community Vitality and Education (Fig.2).

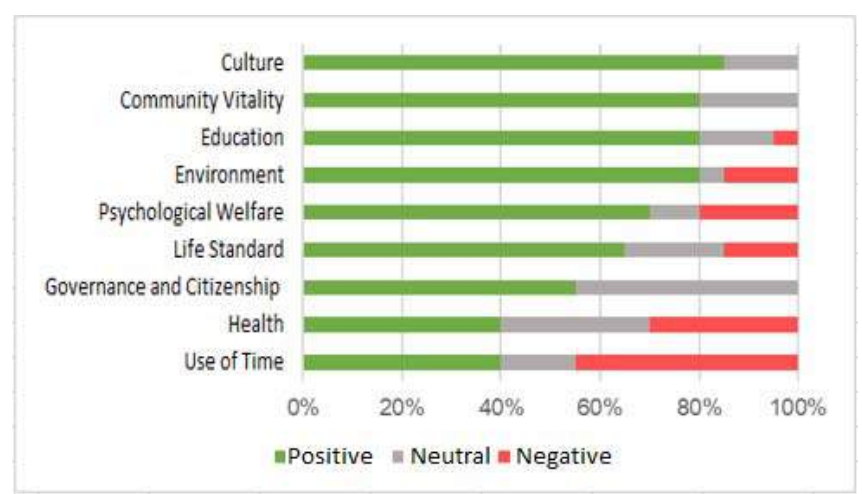

Fig. 2: Total number of perceptions about the dimensions of the Buen Vivir of Social Agents $(N=20)$ of Livramento Community segregated by effect (positive, neutral, or negative) based on the interpretation of the responses obtained by the interviewed SAs.

The dimensions of Buen Vivir are related to both the sphere of private life and that of the community, in different degrees. The following dimensions were considered to have the greatest tendency to the private sector: Psychological Welfare, Use of Time, and Health; in a neutral trend the dimensions: Environment, Governance and Citizenship and Standard of Living; and in a greater tendency towards collectively, the dimensions: Culture, Community Vitality and Education.

Regarding the collective dimensions, the dimensions of Community Vitality, Culture, Environment and Education have an expressive positive quantity, all of which belong to the collective or neutral tendency. Regarding the other perceptions, two dimensions of negative impact, Health and Use of Time, stand out, both in the private sphere. In the analysis of similarity (Fig.2) of the perception of the SAs on the dimensions of Well Being, it is possible to observe three well-defined groups, which here will be called macro cluster (MaC). 


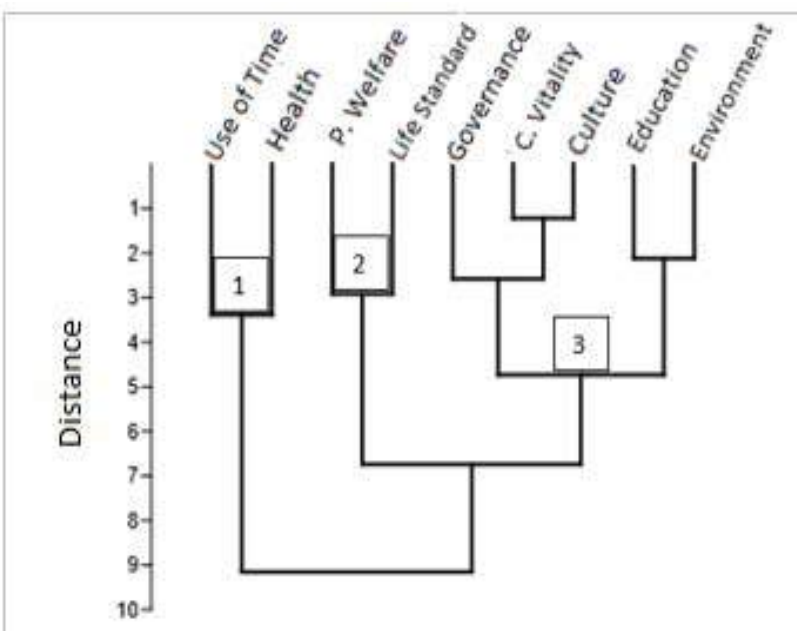

Fig. 3: Graphical representation of the Cluster Analysis carried out from the Dimensions of Buen Vivir $(\mathrm{N}=20)$ by Similarity of Perceptions of the SAs of the Livramento Community - RDS Tupé.

In $\mathrm{MaC} 1$ there are the dimensions of private tendency, Use of Time, and Health, with a lower evaluation and distancing from the others. This indicates that the Use of Time and Health dimension are evaluated in a similar way and interrelated by the SA. In $\mathrm{MaC} 2$ there is a private and a neutral dimension: Psychological Well-Being and Standard of Living. In both, the financial condition and the quality of the housing structure directly impact the perception. In MaC 3 there are two neutral dimensions and the 3 collective dimensions, which are evaluated by everyone in a positive way. It is worth mentioning Community Vitality and Culture, which presented the greatest similarity between dimensions.

RNFEns have a positive impact on the Community's Buen Vivir as a whole. There are similarities in perception between collective dimensions and similarities between private ones, which signals an interinfluence between these dimensions.

\section{b) The Buen Vivir of the Individual to the Collective sphere}

Some dimensions had a negative result in the sum of perceptions, just as individual totals did. According to Morais and Borges (2010), Buen Vivir consists of a qualitative analysis that seeks to understand the individual's impact on the community, so one or another isolated negative case does not distort their contribution to the Community's Buen Vivir.

\section{i. Psychological Welfare}

A concept of quality of life was not pre-defined, leaving the interviewees the possibility to freely associate their impressions. Positive perceptions can reflect impacts beyond the individual and that the improvement in quality of life is associated with the quality of food, for example, since RNFEns benefits food products and that this brings improvements "for both me and my family" (Interview with SA 02, on 20/05/2017).

In general, the RNFEns contribute to a positive psychological welfare for the SAs of Livramento community, as supported by one of the premises of the evaluative concepts of subjective welfare, which signals that a positive result does not imply "exactly in the absence of negative factors, but rather in the predominance of positive affects over negative affects" (ALBUQUERQUE and TRÓCOLLI, 2004, p.154).

\section{ii. Use of Time}

There was an expressive perception about the negative impact in relation to the use of time for other activities not related to work: "time to do my things at home it has decreased, then you must have a control of it, if not, you will not handle both" (interview with SA 05, on 02/06/2017).

The result of the Use of Time dimension expresses meanings in relation to what Seabra (2004) calls two levels of social practice for the definition of ways of using time: territorial insertion and insertion in daily life. On the one hand, the negative result is related to restrictions on certain economic activities and, on the other, insertion in daily life contributes to this result not to worsen, since the SAs combine economic activities with the routine of the people's ways of life of family economic units in the territory.

\section{iii. Community Vitality}

The perception about this dimension is mostly positive regarding SAs engagement in the community. This involvement is directly related to the way in which the activity is performed, which results in an improvement in personal prestige and popularity and social relations, as SA 15 explains: "I became well known in all Communities, Julião, Tupé (São João do Tupé), Ebenézer, Fátima, Agrovila, São Sebastião and Caioé, only Central I have never been" (interview with SA 15 , on $06 / 06 / 2017)$.

As they are cohesive and highly transitive (WATTS and STROGATZ, 1999), social relations are the key point for the result presented in the Community Vitality dimension since Sales et al. (2013) indicate that communication and cooperation between SAs are the necessary instruments for Community Vitality.

\section{iv. Culture}

There is a major perception that the RNFEns contribute to integrate activities and attitudes related to cultural appreciation. The most emphatic reports are about the absorption of private costs in exchange for social benefits in the Community: "(...) at the Community party and whenever there is a tournament (...) I use my transport to bring musicians to the party (...) at the Community party I participate selling and donating some things" (Interview with SA 03, on 23/05/2017). 
Due to the existing valuing of traditional habits and intercultural practices (CRUZ, 2014) present at the Headquarters of the Livramento Community, it is possible to understand the reasons for the Culture dimension not to present negative evaluations. As Boff (2017) pointed out, humans being an integrated and complementary beings with their peers in their actions, having the ability to respect differences, promotes mutual cultural appreciation, since they reflect human diversity.

\section{v. Environment}

The environment is positively affected, as exemplified by SA 16, which states that Cultural Center he/she manages does not only encourage actions aimed at cultural appreciation, but in "(...) sustainability in general, because here they make crafts and one may sell some day, understand the value of it, they take the raw material on the riverbank, take seeds and turn it into something that can serve them later on, right?" (Interview with SA 16, on 23/05/2017).

In areas traditionally occupied by traditional peoples, governmental and civil society projects to encourage the development of sustainable handicrafts, since they dynamize the relations between the visitation of tourists and the performance of projects. This dynamism is beneficial from the perspective of the traditional artisans themselves, as it promotes the physical structure of work, the dissemination of the material and the transmission of knowledge about the maintenance of sustainable practices for the next generations. (Cestari, Caracas and Santos, 2014).

In this perspective, the Cultural Center is a fundamental enterprise as a mediating agency for the sustainability of the Community, in the dynamism between the economic relations of the sale of handicrafts, the environmental relations of obtaining the raw material and the cultural relations of the transmission of the traditional practices of confection.

\section{vi. Governance and Citizenship}

The SAs assess that the RNFEn contributed to a better understanding of their rights and duties as a social agent. Most positive perceptions are linked to the performance of daily activities: "(...) we took the burden of other people who were running this business here (...) and nowadays we find that in the same way who have duties, we have priorities" (interview with SA 12, on 20/05/2017).

The role of SAs in the Governance and Citizenship dimension represents a potential to be worked on, since participatory strategies can "(...) contribute to strengthen community bonds of solidarity and increase the technical and political power of communities in decision-making processes (FREITAS, 2004, p.152).

\section{vii. Life Standard}

As in the Psychological Welfare dimension, there is an emphasis on the signs of belonging, with housing as the main influence on the Life Standard, which corroborates the similarity already presented previously. The fact that some SAs do not relate income to the standard of living can be understood more clearly in the collective and cultural construction of the concept of standard of living peculiar to the Community. In their existential daily life, based on cultural relativity (MINAYO, HARTZ and BUSS, 2000), we tried to understand what this conception is and its influences on the collective of SAs and not on the individual. This line presents an important contribution to think of Buen Vivir as a paradigmatic instrument of opposition to modernist/ colonial development.

viii. Health

Regarding the perception of Health, in both positive and negative there are directly linked to the Use of Time. RNFEn has a negative impact on health when linked to manual activities: "It got worse, I don't do the kind of work I used to do (...) because I don't have that skill anymore, but at the end of the day I think it's worse to work like this, because working a lot while the blood doesn't circulate". (Interview with AS 14, on 12/08/2017).

\section{ix. Education}

Of the perceptions that indicated a positive impact in education, it is worth highlighting those that express the improvement in learning. SA 11 reported the importance for him/herself and other SAs of the actions carried out by the association: "Today we have come to know people of different habits (...) and this has changed a lot our communication, we end up learning from parentes [expression used to refer someone from any other ethnic group] and even from white people. We had 3 students here who went to State University of Amazonas and did pedagogy and are trained, and it was through the Association". (Interview with SA 11, on 05/03/2017). For Seabra (2004), social practices have two levels, one of territorial insertion and another of insertion in daily life. Thus, there is a positive influence when this SA is inserted in daily life, integrating the spaces of use of the Community with the activities developed.

\section{c) Influence of socioeconomic profile factors on the perception of SAs}

The principal component analysis was carried out from the perception's matrix (Fig. 3) and used for grouping and dispersing the SAs' responses and perceptions patterns. Principal components 1 and 2 together explain $54.84 \%$ of the variance (PC1 35.36\%; PC2 19.48\%) of perceptions.

To detect which socioeconomic variable could be related to the perception patterns of the SAs, the values of PC1 were used as a dependent variable in a multiple regression where the independent variables 
were the socioeconomic characteristics of the RNFEns (Fig. 1). Among the variables analysed (Fig. 1), the one that showed significant results was pluriactivity, that is, the number of activities developed by the SAs $\left(r^{2}=0.3465, p=0.0063\right)$ (Fig. 3).

Those with up to 2 activities rated only 0.5 dimensions negatively, on average. Those with 3 and 4 activities negatively rated 1.75 and 2.3 dimensions, on average, respectively. This indicates that the greater the number of activities that a SA develops, the greater the tendency of this SA to perceive that RNFEn negatively influences the dimensions of Buen Vivir, especially those with greater individual impact, such as Health and Use of Time (Fig. 2).

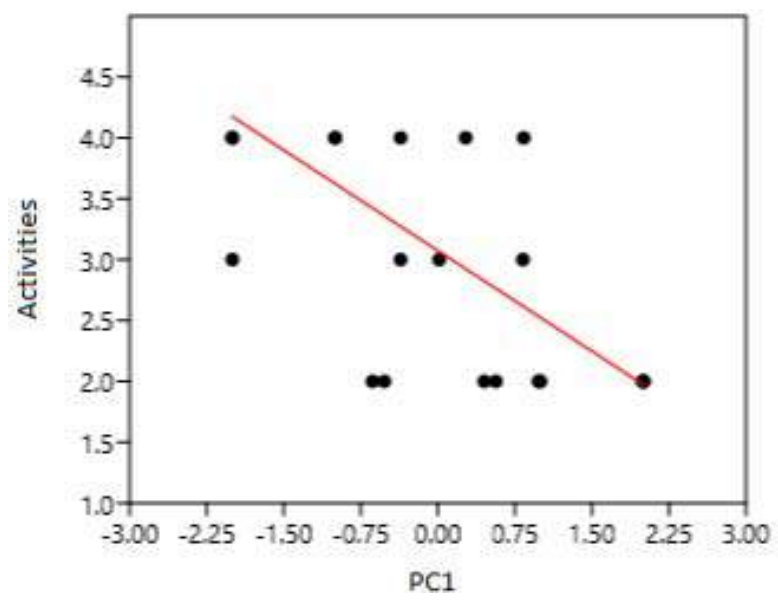

Fig. 3: Principal Component 1 regression analysis in relation to pluriactivity $(\mathrm{r} 2=0.3465)$.

\section{Conclusion}

Exploring with the concept of Buen Vivir as a theoretical and methodological basis for the analysis of collective dimensions proved to be effective to capture the qualitative perception of SAs on the impact of their enterprises on the Buen Vivir of Communities living in protected areas in the Amazon. The RNFEns, in addition to being an economical alternative to face the restrictions on the use of natural resources imposed in protected areas, can represent a significant and recognized contribution to the Buen Vivir of resident populations.

In turn, the cluster analysis points to mutual influences between some dimensions, which confirms that these dimensions must be understood in a systemic way. SAs tend to evaluate similarly and positively or neutrally the influence of RNFEns on the collective dimensions of Buen Vivir: Governance and Citizenship, Community Vitality, Environment, Culture and Education. The dimensions Psychological Welfare and Life Standard Living are the dimensions most strongly interrelated. The dimensions of Health and Use of Time are also related, but in the similarity of negative perceptions.
Regarding the influence of the socioeconomic variables of the RNFEns on the perception of the SAs, only the variable indicating pluriactivity was related to the variation in the perception patterns between the SAs. The greater the number of activities that an SA develops within an RNFEn, the greater the tendency the SA to negatively assess private dimensions, such as Health and Use of Time.

We can conclude that the RNFEns positively impact the Livramento Community Buen Vivir, with emphasis on the dimensions of collective tendency, such as Education, Culture, and Community Vitality, however there is a need for attention to those SAs who develop more than 3 activities in their RNFEN.

\section{ACKNOWledgments}

This study was financed in part by the scholarship to the first author by Coordenação de Aperfeiçoamento de Pessoal de Nível Superior - Brasil (CAPES). We are grateful for the support given by the State Agency to support Research of Amazonas (FAPEAM/AM/BRAZIL), Graduation Program of Environmental Sciences and Sustainiability in Amazon (PPGCASA)"

\section{References Références Referencias}

1. Acosta, A. (2012) O Buen Vivir - uma oportunidade de imaginar outro mundo. In: BARTELT, Dawid Danilo (Ed.). Um campeão visto de perto. Uma análise do modelo de desenvolvimento brasileiro. Rio de Janeiro: HeinrichBöll-Stiftung.

2. Albuquerque, A. S. and Trócolli, B. T. (2004) Desenvolvimento de uma Escala de Bem-Estar Subjetivo. Revista Psicologia: Teoria e Pesquisa, 20(2), p.153-165.

3. Alcantara, L. C. S. and Sampaio, C. A. C (2017a) Bem Viver como paradigma de desenvolvimento: utopia ou alternativa possível? Revista Desenvolvimento e Meio Ambiente, 40, p. 231-251.

4. Alcantara, L. C. S. and Sampaio, C. A. C (2017b) Bem Viver: uma perspectiva (des) colonial das comunidades indígenas. Revista Rupturas. San Pedro de Montes de Oca, 7(2).

5. Almeida, A. W. B. (2008). Terras de quilombo, terras de indígenas, "babaçuais livres", "castanhais do povo", faxinais e fundos de pastos: terras tradicionalmente ocupadas. Manaus: PPGSCAUFAM.

6. Atawallpa, O. F. (2014). Sumak kawsay/cultura de la vida: más allá del socialismo y del capitalismo, camino alternativo al desarrollo. Sumak Editores.

7. Bachelard, G. (1996). A formação do espírito científico: contribuição para uma psicanálise do conhecimento. Rio de Janeiro: Ed. Contraponto.

8. Bardin, L. (2009) Análise de conteúdo. São Paulo: Edições 70. 
9. Baumel, A.; Basso, L. C. (2004). Agricultura familiar e a sustentabilidade da pequena propriedade rural. In: Gisele Camargo; Maurício Camargo Filho; Jorge Luiz Fávaro (Eds.) Experiências em desenvolvimento sustentável e agricultura familiar. Guarapuava - Paraná: Ed. Unicentro.

10. Berdegue, J. (2019). Carta aberta de Julio Berdegue, Representante Regional da FAO. Década da Agricultura Familiar. FAO no Brasil: Organização das Nações Unidas para a Alimentação e a Agricultura. Available in: fao.org/ brasil/noticias/detail-events/pt/c/1206221/.

11. Boff, L. (2017). Sustentabilidade: o que é - o que não é. Petrópolis, RJ. Editora Vozes.

12. Bourdieu, P. (2008). Compreender. In: A Miséria do Mundo. $7^{\mathrm{a}} \mathrm{ed}$. Petropolis, Rio de Janeiro: Vozes.

13. BRASIL - SNUC - Sistema Nacional de Unidades de Conservação (2000). Lei No 9.985, DE 18 De Julho De 2000, Lei que regulamenta o art. 225, § 10, incisos I, II, III e VII da Constituição Federal, institui o Sistema Nacional de Unidades de Conservação da Natureza e dá outras providências.

14. BRASIL - PNPCT - Política Nacional de Desenvolvimento Sustentável dos Povos e Comunidades Tradicionais (2007). Decreto $\mathrm{n}^{\circ}$ 6.040 , de 7 de fevereiro de 2007. Decreto que institui a Política Nacional de Desenvolvimento Sustentável dos Povos e Comunidades Tradicionais.

15. Capellesso, A. J. and Cazella, A. A. (2011). Pesca artesanal entre crise econômica e problemas socioambientais: estudo de caso nos municípios de Garopaba e Imbituba (SC). Ambiente e sociedade, São Paulo, 14(2), p.15-33.

16. Cestari, G. A. V., Caracas, L. B., Santos, D. M. (2014) Artesanato tradicional, design e sustentabilidade: com a palavra quem produz cerâmica em Itamatatiua. Strategic Design Research Journal, 7(2), p.84-94.

17. Costa, A. M. and Kühn, D. D. (2019). Bien Vivir/Buen Viver/Bem Viver: uma proposta de pósdesenvolvimento nas Epistemologias do Sul. Revista IDeAS. Rio de Janeiro: UFRRJ, 11(1-2), p.34-66.

18. Cruz, J. G. (2015). Organização político-cultural e interculturalidade na gestão dos territórios indígenas para o bem viver no rio Negro-AM. Tese (Doutorado em Ciências do Ambiente e Sustentabilidade na Amazônia) - Universidade Federal do Amazonas.

19. De-Silva, L. and Kodithuwakku K. (2010) Pluriactivity and Socio-economic Success of Rural Households. Sri Lankan. Journal of Agricultural Economics, 7, pp. 85-108.

20. Endere, M. L. and Zulaica, M. L. (2015). Sustentabilidad Socio-Cultural Y Buen Vivir En Sitios
Patrimoniales: Evaluación Del Caso Agua Blanca, Ecuador. Ambiente e Sociedade, São Paulo, 18(4), p. 265-290.

21. Evans, N.J. and Ilbery, B. W. (1993). The pluriactivity, part-time farming, and farm diversification debate. Environment and planning A, 25.

22. Faiguenbaum, S., Berdegue, J.A. and Reardon, T. (2002). The Rise of Supermarkets in Chile: Effects on Producers in the Horticulture, Dairy, and Beef Chains. Development Policy Review. 20, p.459-471.

23. Freitas, C. M. (2004). Ciência para a Sustentabilidade e a Justiça Ambiental. In: Henri Acselrad; Selene Herculano e José Augusto Pádua (Eds.) Justiça ambiental e cidadania. Rio de Janeiro: Relume Dumará: Fundação Ford, p. 141-157.

24. Fuller, A. M. (1990). From part-time farming to pluriactivity: a decade of change in Rural Europe. Journal of Rural Studies, 6(4), p. 361-373.

25. Haggblade, S., Hazell, P. and Reardon, T. (2010). The Rural Non-farm Economy: Prospects for Growth and Poverty Reduction. Elsevier: Word Development, 38(10), p.1429-1441.

26. Haggblade, S., Reardon, T. and Hyman, E. (2007). Technology as a motor of change in the rural nonfarm economy. In: Haggblade S, Hazell $P$, Reardon $T$ (Eds.), Transforming the rural nonfarm economy: Opportunities and threats in the developing world. Baltimore: Johns Hopkins University Press, p.322-351.

27. Hammer, Ø., Harper, D. A. T. and Ryam, P.D. (2001) PAST: Paleontological statistics software package for education and data analysis. Palaeontologia Electronica, 4(1), 9 pp.

28. Hongyu, K., Sandanielo, V. L. M. and OliveiraJunior, G. J. (2016). Análise de Componentes Principais: resumo teórico, aplicação e interpretação. Engineering and Science, 1(5), p. 83-90.

29. IHU (INSTITUTO HUMANITAS UNISINOS). (2010). Sumak Kawsa, Suma Qamaña, Teko Porã. O BemViver. Revista IHU On-Line. São Leopoldo.

30. Kinsella, J., Wilson, S., De-Jong, F. and Renting, H. (2000). Pluriactivity as a Livelihood Strategy in Irish Farm Households and its Role in Rural Development. Sociologia Ruralism, 1(40), p. 481-496.

31. Kothari, A., Demaria, F. and Acosta, A. (2015). Buen Vivir, Degrowth and Ecological Swaraj: Alternatives to Sustainable Development and the Green Economy. Development, 57(3), p. 362-375.

32. Krajewski, L. J., Ritzman, L. P. and Malhotra, M. (2009). Administração da produção e operações. 8. ed. São Paulo: Pearson Prentice Hall. 
33. Lacerda, R. F. and Feitosa, S. F. (2015). Bem Viver: Projeto U-tópico e De-colonial. Interritórios - Revista de Educação Universidade Federal de Pernambuco. Caruaru, Pernambuco, 1, p.05-23.

34. Loughrey, J., Donnellan, T., Hennessy, T. and Hanrahan K. (2013). The Role of Pluriactivity in Farm Exit and Labour Supply Decisions. Factor Markets Working Paper, 1(67), p.01-11. 